specialists in any aspect of humanity in the Arctic. (Piers Vitebsky, Scott Polar Research Institute, University of Cambridge, Lensfield Road, Cambridge CB2 1ER)

\section{HERDING IN PERSPECTIVE}

THE WORLD OF PASTORALISM: HERDING SYSTEMS IN COMPARATIVE PERSPECTIVE. Galaty, J. and Johnson, D. L. (editors). 1990. London, Guilford Press and Belhaven Press. 436 p, illustrated, hard cover. ISBN 1-85293-176-0.

This is a useful compendium of information on pastoral systems in all ecological zones, from African cattle to Andean camelids. It is a good textbook for anthropologists and geographers and the authors pay particular attention to the development dimension.

The article likely to be of main interest to polar readers is Hugh Beach's on 'Comparative systems of reindeer herding', covering Fennoscandia, Alaska, the USSR, Greenland and Canada. Beach discusses common denominators and local variations, covering both the environment and the ethnic and political struggles which have arisen at the margins of powerful industrial states, as well as conflicts with industrialisation and the decline of recruitment and the trend towards the cash economy. Much of the general discussion applies only to Fennoscandia, though this is not always made clear, and the author's experience and sources come largely from this region.

The article's weakness as a comparative survey lies in its coverage of the Soviet Union, which contains nearly $80 \%$ of the world's domesticated reindeer and where reindeer form the foundation of vast regional economies. Without Russian, Beach has relied on a very limited range of sources, as well as on a visit to a state farm in Yakutia. But the debates and policy dilemmas which he understands well in Fennoscandia are inaccessible without extensive reading in the large and controversial Russian literature; while it would help the reader to be told that the farm he visited is a showpiece to which foreigners are often escorted and is far from typical. On the basis of longer fieldwork in the region, it is hard to agree unequivocally that 'reindeer herding faces its brightest future in the Soviet Union', that extractive industries there have not pressed herding to the wall, or that the state is working to remedy the drop in recruitment.

However, the general discussion and the picture of reindeer herding given for the other countries are very helpful and there is an excellent classified entry in the index under 'reindeer' which occupies almost three columns. (Piers Vitebsky, Scott Polar Research Institute, University of Cambridge, Lensfield Road, Cambridge CB2 1ER.)

\section{BRIEF REVIEWS}

NORTHWESTPASSAGE: THEQUESTFOR AN ARCTIC ROUTE TO THE EAST. Struzik, E. and Beedell, $M$. 1991. London, Blandford Press. 152 p, illustrated, hard cover. ISBN 0-7137-2246-0. $£ 16.95$.

Struzik is a journalist, Beedell a photographer: both have ample first-hand experience of the Passage, and their joint account of it is a delight. The text is a blend of history, natural history, anthropology, geography, personal stories and good yarns from the past. The photographs - 60 in colour and almost as many in black and white - are quite superb. A marvellous book to give anyone as an afterChristmas present.

SAAMI CULTURAL RESEARCH IN SWEDEN 1990. Kvist, R. 1991. Centre for Arctic Cultural Research, Umeå University (Miscellaneous Publications 11). 57 p, soft cover. ISSN 0283-9687.

READINGS IN SAAMI HISTORY, CULTURE AND LANGUAGE II. Kvist, R, 1991. Centre for Arctic Cultural Research, Umeâ University (Miscellaneous Publications 12). $158 \mathrm{p}$, illustrated, soft cover. ISSN 0283 9687.

Two publications from a lively Swedish source. The first, a catalogue of one-page summaries of current or recentlycompleted Swedish Saami cultural studies, will be of interest to anyone involved in similar studies in the humanities, social sciences, physical anthropology and theology. The second is a collection of articles in English on Saami culture, history and language, with perspectives on culture and research: four of the articles are on archaeology and the remaining six from ethnology, history, anthropology and linguistics: subjects range from the prehistoric use of pitfalls in Asele Lappmark to a Saami strategy for language preservation. Obtainable from the Centre, University of Umeå, S-901 87, Umeå, Sweden.

THE STATE OF THE ARCTIC ENVIRONMENT. Prepared by Nenonen, M. 1991. Rovaniemi, University of Lapland. 405 p, illustrated, soft cover. ISBN 951-634231-0.

Arising from a series of meetings between scientists from the Arctic countries, this volume presents six state-of-theenvironment reports on aspects of international cooperation in environmental protection. Articles cover manmade acidification (Nenonen), heavy metals (Melnikov), underwater noise (Davis and others), oil pollution (Futsaeter and others), organochlorines (Jensen) and radioactivity (Paakkola). Obtainable from the Arctic Centre, University of Lapland, PO Box 122, 96101 Rovaniemi, Finland.

BACK FROM THE BRINK: THE ROAD TO MUSKOX CONSERVATION IN THE NORTHWEST TERRITORIES. Barr, W. 1991. Calgary, University of Calgary (Komatik Series 3). 127 p, illustrated, soft cover. ISBN0919034-67-5. Can $\$ 23.00$ including postage.

A detailed account of the decline of muskoxen under hunting pressures during the 19 th century, and their subsequent recovery under protection. Formerly widespread on most of the Canadian Arctic islands and across the mainland between Anderson River in the northwest and Rae Isthmus and Churchill in the east, they were hunted commercially for meat, hides and furs. Mainland populations, reduced to a few hundred by 1917 , have now recovered to over 13,000 . The author tells their story within the context of Canadian history, relating - among other curious events - how threats to the species led to the establishment of a Canadian presence in the high Arctic, and 
legislation to control not only the exploitation of muskoxen but also the activites of foreign scientists and explorers in the far north.

SEAWEEDS OF THE BRITISH ISLES: VOL 2 CHLOROPHYTA. Burrows, E. M. 1991. London, Natural History Museum. 238 p, illustrated, soft cover. ISBN 0-565-00981-8. £27.00.

The second of seven volumes on British seaweeds, resulting from a collaborative project between the British Phycological Society and the British Museum (Natural History). Illustrated and keyed for identifications with,, sadly, only a very few black and white plates. Of value to polar workers because many of the species spread far north into the Arctic.

FROM ANTARCTICA TO OUTER SPACE: LIFE IN ISOLATION AND CONFINEMENT. HARRISON, A. A. A, Clearwater, Y. A. and McKay, C. P. (editors). Berlin, Springer Verlag. 410 p, illustrated, hard cover. ISBN 3-540-97310-9. DM78.00.

Edited proceedings of the 1987 Sunnyvale Conference sponsored by the Division of Polar Programs of the US National Science Foundation and the National Aeronautics and Space Administration, to discuss common interests in studies of isolated and confined people. Of great interest to all concerned with recruiting men and women for long-term space flight and polar programmes. Old hands at either may be hard pressed to accept many of the parallels assumed between the two fields of endeavour, and perhaps feel the need for less euphoric agreement and more dissenting voices.

GENETICECOLOGY OF WHALES AND DOLPHINS. Hoelzel, A. R. (editor). 1991. Cambridge, International Whaling Commission (Special issue 13). 311 p, illustrated, hard cover. ISBN 0-906975-25-5. £30.00 (US\$62.00) including postage.

A volume arising from a workshop in La Jolla, 1989, to investigate molecular genetic techniques in analysis of whale and dolphin stocks - part of the IWC's strategy of world stock identification and assessment. Over 20 papers cover stock boundaries, methodology, population studies, and a summary and analysis of results. Obtainable from the International Whaling Commission, The Red House, Station Road, Histon, Cambridge CB4 4NP.

LIVING ICE: UNDERSTANDING GLACIERS AND GLACIATION. Sharp, R. P. 1991. Cambridge, Cambridge University Press. 225 pages, illustrated, soft cover. ISBN 0-521-40740-0. £10.95, US\$15.95.
Reissue in soft covers (with amendments) of a text published originally in 1988. See the review by John Splettstoesser in Polar Record 25(155): 356-57 (October 1989), who described the hard-cover version as a genuine bargain: this issue is roughly one third cheaper in sterling and half as cheap in dollars.

MAWSON'S PAPERS. Innes, $M$. and Duff, $H$. (compilers). 1991. Adelaide, Mawson Institute for Antarctic Research. 302 p, illustrated, soft cover. ISBN 0-86396107-X. A $\$ 49.00$ including postage.

A most comprehensive catalogue of the scientific, personal and business papers of Sir Douglas Mawson, including a biography and bibliography of original and secondary sources. A complete study of the Mawson archives, fully indexed and cross-referenced. Obtainable by mail order from Adelaide University Library.

THE CAMPUS SITE: A PREHISTORIC CAMP AT FAIRBANKS, ALASKA. Mobley,C.M. 1991. Fairbanks, University of Alaska Press. 104 p, illustrated, soft cover. ISBN 912006-52-8. US\$22.00 including postage.

Monograph of an archaeological site which,from first reports in 1934, was thought to represent an occupation of $8000-12,000$ years ago, to have artifacts '... identical ... with thousands of specimens found in the Gobi desert' and thus to fumish '... the first clear archaeological evidence we have of early migration to the American continent'. Mobley's assessment of the site, now on the University campus, is more thorough, less exciting, but no less engrossing, indicating a more recent first occupation of some 3000 years, complicated by many reoccupations and reworkings of the material.

DIRECTORY OF EXPERTISE IN AUSTRALIA: ANTARCTICA AND THE SOUTHERN OCEAN. Lyons, D. J. (compiler). 1991. Hobart, Instritute of Antarctic and Southern Ocean Studies. 53 p, soft cover. $\$ 10.00$ including postage.

Compiled as '... a reference source for researchers and others seeking professional advice or information on Antarctica and the Southern Ocean ... intended to improve communications and collaboration ...'. Data include names of all contributing Australian workers, fields of study, current interests and projects, addresses, telephone and fax numbers. A useful early contribution (optimistically labelled 'first edition') from Australia's newest and most promising Antarctic institution. Obtainable by mail order from the Institute, University of Tasmania, Box 252C, Hobart, Tasmania, Australia 7001. 